\title{
Profil Diare Akut dengan Dehidrasi Berat di Ruang Perawatan Intensif Anak
}

\author{
Jeannete I.Ch. Manoppo \\ Departemen Ilmu Kesehatan Anak, Universitas Sam Ratulangi RSU Prof. Dr. R.D. Kandou, Manado
}

\begin{abstract}
Latar belakang. Diare merupakan penyakit penyebab kematian nomor dua pada anak kurang dari 5 tahun dan memberikan kontribusi kematian 1,5 juta anak per tahun.Kebanyakan anak meninggal karena dehidrasi berat.

Tujuan. Untuk mengetahui karakteristik, manifestasi klinis, dan temuan laboratorium anak diare akut dengan dehidrasi berat.

Metode. Penelitian deskriptif retrospektif, dilakukan pada bulan Januari 1999-Desember 2008. Data diambil dari rekam medik RSU Prof. Dr. R.D. Kandou, Manado dan dianalisis dengan SPSS 17.0.

Hasil. Terdapat 83 anak, terbanyak usia kurang dari 1 tahun $(60,2 \%)$, laki-laki $(73,5 \%)$, dan status gizi kurang $(36,1 \%)$. Lama diare \pm 2.54 hari dengan keluhan lain yang terbanyak adalah demam dan muntah (73,3\%). Komplikasi yang terbanyak dijumpai berupa gangguan keseimbangan elektrolit $(62,5 \%)$. Pemeriksaan laboratorium, hematokrit 33,8\% (23,1-52\%), hemoglobin $11,3 \mathrm{~g} / \mathrm{dL}(7,8-16,5 \mathrm{~g} / \mathrm{dL})$, dan leukosit $15.360 / \mathrm{mm}^{3}\left(4.000-41.700 / \mathrm{mm}^{3}\right)$. Dari 20 sediaan feses yang diperiksa ditemukan Kandida sp (75\%), Blastosistosis hominis (40\%), E. coli (25\%), Koliform (5\%) dan Ascarias lumbricoides (5\%).

Kesimpulan. Diare akut dengan dehidrasi berat ditemukan pada bayi laki-laki, dengan komplikasi terbanyak gangguan keseimbangan elektrolit (seperti hipokalemia) dan sepsis. Kandida sp merupakan patogen yang paling banyak ditemukan pada pemeriksaan feses. Sari Pediatri 2010;12(3):157-61.
\end{abstract}

Kata kunci: diare akut, dehidrasi berat

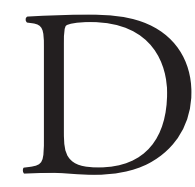
iare akut dengan dehidrasi masih merupakan penyebab kesakitan di dunia dan pada beberapa negara berkembang sebagai penyebab utama kematian..$^{1-3}$ Diare pada anak didefenisikan sebagai perubahan

\footnotetext{
Alamat korespondensi:

Dr. Christie Manoppo, Sp.A. Bagian Ilmu Kesehatan Anak FK UNSRAT/RSU Prof. Dr. R.D. Kandou Manado. Telp. (0431) 821652, Fax. (0431) 859091.
}

kebiasaan buang air besar yang normal yakni peningkatan volume $(>10 \mathrm{~mL} / \mathrm{kgbb} / \mathrm{hari})$ pada bayi dan anak dan/atau penurunan konsistensi feses $(>3$ kali dalam sehari). ${ }^{4}$ Diare akut pada umumnya terjadi kurang dari 7 hari dan tidak lebih dari 14 hari. ${ }^{5,6}$ Tingkat keparahannya dapat berhubungan dengan usia anak, status nutrisi, dan penyebab yang mendasari terjadinya diare. Diare merupakan mekanisme pertahanan tubuh, mengeliminasi organisme infeksius dengan cepat, namun dapat menimbulkan komplikasi 
yang serius seperti dehidrasi, khususnya pada anak malnutrisi atau keadaan imunosupresi. ${ }^{7}$

Diperkirakan 2 sampai 2,5 juta kematian yang berhubungan dengan diare terjadi pada anak kurang dari 5 tahun, terkonsentrasi pada daerah miskin di dunia. ${ }^{8,9}$ Perkiraan pada tahun 1990-an sekitar 1,4 juta episode diare terjadi setiap tahun pada anak kurang dari 5 tahun di negara berkembang. ${ }^{1}$ Pada populasi ini menunjukkan median 3,2 episodik diare pada anak tiap tahun. ${ }^{9}$ Pada daerah yang masih dijumpai malnutrisi berat, 6-8 episode diare terjadi pada anak setiap tahun seperti yang dilaporkan oleh Guandalini., ${ }^{5} 10$ Penyebab diare akut umumnya infeksi gastrointestinal, dengan infeksi virus merupakan penyebab tersering. Pada daerah maju, rotavirus dijumpai pada $25-40 \%$ kasus. ${ }^{5,10}$ Patogenesis diare akut adalah multifaktorial dan dapat disebabkan oleh patogen lain. Kenyataannya, lebih dari 20 virus, bakteri dan parasit enteropatogen dapat menyebabkan diare. ${ }^{11}$ Penyebab lainnya yang telah diketahui adalah obat-obatan, alegi makanan, gangguan absorbsi dan pencernaan, defisiensi vitamin atau tertelan logam berat. ${ }^{5}$

Gejala tambahan yang berhubungan dengan diare akut yakni nyeri perut, demam, dan muntah., ${ }^{5,12,13}$ Anak dengan gastroenteritis atau penyakit lain yang menyebabkan muntah, diare, atau asupan makanan yang rendah berisiko mengalami dehidrasi. ${ }^{3}$ Evaluasi klinis pada umumnya difokuskan pada penilaian keparahan dehidrasi serta identifikasi penyebab berdasarkan riwayat dan temuan klinis. ${ }^{14}$

Standar emas untuk mendiagnosis dehidrasi adalah dengan mengukur kehilangan berat badan akut tetapi oleh karena berat badan sebelum sakit pada umumnya tidak diketahui, maka perkiraan kehilangan cairan dilakukan berdasarkan penilaian klinis. ${ }^{3}$ Penilaian klinis dehidrasi berbeda-beda. Penilaian menurut World Gastrointestinal Organization (WGO) meliputi kesadaran, mata cekung, rasa haus, serta turgor kulit. ${ }^{14}$ Menurut Guandalini, penilaian dehidrasi yang paling baik adalah menilai pemanjangan pengisian kapiler perifer, turgor kulit, dan pola pernafasan. ${ }^{15}$ Kegagalan menegakkan diagnosis dehidrasi mengakibatkan peningkatan morbiditas dan mortalitas, sedangkan overdiagnosis menimbulkan penggunaan sumber kesehatan yang berlebihan. ${ }^{3}$

Penelitian dilakukan dengan tujuan untuk mendeskripsikan karakteriskik, gambaran klinis, dan laboratorium pasien diare akut dehidrasi berat di ruang perawatan intensif anak RSUP. Prof. Dr. R.D. Kandou, Manado.

\section{Metode}

Telah dilakukan penelitian deskriptif secara retrospektif, dari Januari 1999 sampai Desember 2008 data diperoleh dari rekam medik pasien diare akut dehidrasi berat yang dirawat di ruang perawatan intensif anak RSUP. Prof. Dr. R.D. Kandou, Manado. Data dianalisis secara komputerisasi dengan menggunakan program SPSS 17.0. Semua pasien yang dirawat di ruang perawatan intensif dengan diagnosis diare akut dehidrasi berat dimasukkan dalam penelitian.

Diare akut pada anak didefenisikan sebagai perubahan kebiasaan buang air besar yang normal yakni peningkatan frekuensi $(>10 \mathrm{~mL} / \mathrm{kgbb} /$ hari pada bayi dan anak) dan/atau penurunan konsistensi feses (>3 kali dalam sehari). ${ }^{4}$ Diare akut adalah diare kurang dari 7 hari. ${ }^{5,6}$ Kriteria penilaian tingkat keparahan dehidrasi menggunakan kriteria World Health Organization (WHO), mencakup penilaian keadaan umum, mata cowong, air mata, mukosa mulut dan lidah, rasa haus, serta turgor kulit. ${ }^{16}$

\section{Hasil}

Sejak Januari 1999 sampai Desember 2008 di ruang perawatan intensif BLU. RSUP. Prof dr R.D. Kandou, Manado, telah dirawat 83 pasien yang didiagnosis diare akut dehidrasi berat. Terbanyak kelompok umur $<1$ tahun $(60,2 \%)$, laki-laki $(73,5 \%)$, dan gizi kurang (36,1\%).

Pasien umumnya datang dengan berbagai gejala diare $(100 \%)$, demam dan muntah $(73,2 \%)$, batuk $(14,5 \%)$ dan kejang $(8,4 \%)$ dengan lama rawatan di rumah sakit sekitar 2,5 hari. Komplikasi yang didapatkan berupa gangguan keseimbangan elektrolit $(62,5 \%)$ disusul oleh sepsis $(73,3 \%)$, renjatan hipovolemik $(8,4 \%)$, bronkopneumonia $(2,4 \%)$, dan ensefalitis (12\%). Gambaran karakteristik pasien tersebut tertera pada Tabel 1.

Pasien mendapat pengobatan berdasarkan protokol terapi dehidrasi menurut WHO dan semua pasien sembuh. Gambaran laboratorium yang diperoleh tertera pada Tabel 2.

Di antara 83 kasus, 20 kasus dilakukan pemeriksaan feses lengkap dan kultur feses. Hasil dari pemeriksaan tersebut tertera pada Tabel 3.

Lama rawat rata-rata di rumah sakit sekitar 5,5 hari (SD 3,3 hari). Pengobatan yang diberikan adalah 
Tabel 1. Gambaran karakteristik, gejala klinis, dan komplikasi

\begin{tabular}{|c|c|c|}
\hline & Jumlah & $\begin{array}{c}\text { Persentase } \\
(\%)\end{array}$ \\
\hline \multicolumn{3}{|l|}{ Umur } \\
\hline$<1$ tahun & 50 & 60,2 \\
\hline $1-5$ tahun & 28 & 33,7 \\
\hline$>5$ tahun & 5 & 6 \\
\hline \multicolumn{3}{|l|}{ Jenis kelamin } \\
\hline Laki-laki & 61 & 73,5 \\
\hline Perempuan & 22 & 26,5 \\
\hline \multicolumn{3}{|l|}{ Status nutrisi } \\
\hline Gizi lebih & 5 & 6,1 \\
\hline Gizi baik & 24 & 28,9 \\
\hline Gizi kurang & 30 & 36,1 \\
\hline Gizi buruk & 24 & 28,9 \\
\hline \multicolumn{3}{|l|}{ Gejala } \\
\hline Diare & 100 & 100 \\
\hline Demam & 61 & 73,3 \\
\hline Muntah & 61 & 73,3 \\
\hline Batuk & 12 & 14,5 \\
\hline Kejang & 7 & 8,4 \\
\hline \multicolumn{3}{|l|}{ Komplikasi } \\
\hline Gangguan keseimbangan elektrolit & & 60,5 \\
\hline Sepsis & & 20,5 \\
\hline Ensefalitis & & 1,2 \\
\hline Bronkopneumonia & & 2,4 \\
\hline Syok hipovolemik & & 8,4 \\
\hline
\end{tabular}

Tabel 2. Gambaran hasil pemeriksaan laboratorium

\begin{tabular}{lccc}
\hline Laboratorium & Rata rata & Modus & Rentang \\
\hline Hemoglobin $(\mathrm{g} / \mathrm{dL})$ & 11,26 & 10,9 & $7,6-17,6$ \\
Hematokrit $(\%)$ & 33,8 & 38 & $20-52$ \\
Leukosit $\left(/ \mathrm{mm}^{3}\right)$ & $15.359,8$ & 5.400 & $4.000-$ \\
& & & 41.7000 \\
Natrium $(\mathrm{mg} / \mathrm{dL})$ & 136,6 & 135 & $117-154$ \\
Kalium $(\mathrm{mg} / \mathrm{dL})$ & 3,6 & 3,0 & $1,5-9,7$ \\
Klorida $(\mathrm{mg} / \mathrm{dL})$ & 104,7 & 109 & $90-131$ \\
\hline
\end{tabular}

Tabel 3. Hasil pemeriksaan feses lengkap dan biakan feses

\begin{tabular}{lc}
\hline Hasil biakan & $\mathrm{n}$ \\
\hline Kandida & 15 \\
Vibrio Cholera & 1 \\
Blastosistosis hominis & 8 \\
Ascaris lumbricoides & 1 \\
Koliform & 1 \\
E. coli & 5 \\
\hline
\end{tabular}

dengan pemberian cairan ringer laktat / ringer asetat, sebagian mendapat terapi antibiotik, zink, probiotik, dan antipiretik.

\section{Pembahasan}

Diperoleh kejadian diare akut dehidrasi berat pada anak yang dirawat di perawatan intensif RSUP. Prof. Dr. R.D. Kandou, Manado yang terbanyak pada anak di bawah satu tahun (60,5\%). Seperti penelitian Baqui dkk, ${ }^{17}$ yang dilakukan di daerah pedalaman Bangladesh pada tahun 1992, angka kejadian diare tertinggi pada dua tahun pertama kehidupan dan terbanyak umur 6-11 bulan. Insidens dan risiko mortalitas penyakit diare lebih banyak dijumpai pada anak kurang dari satu tahun dan setelah itu menunjukkan penurunan. ${ }^{1}$ Penelitian di Rumah Sakit Munimbili Nasional (18 Feb - 08 Maret 2008), memperlihatkan sekitar $60 \%$ pasien diare akut adalah laki-laki dan terbanyak pada usia 7-12 bulan. ${ }^{18}$ Pada penelitian kami diare akut dehidrasi berat lebih sering pada laki-laki (73,5\%). Hal ini mungkin disebabkan higiene yang jelek dan paparan terhadap dunia luar lebih besar pada anak laki-laki dibandingkan perempuan. Penelitian oleh Mallory $\mathrm{dkk}^{19}$ memperlihatkan bahwa gastroenteritis akut dengan dehidrasi lebih sering pada laki-laki (55\%) dengan rata-rata umur 1,8 tahun dan median umur 1,16 tahun, tetapi beberapa penelitian menyebutkan tidak dijumpai perbedaan bermakna antara anak laki-laki dengan perempuan. ${ }^{1,10}$ Perempuan memiliki insidens yang tinggi terhadap Campilobacter spesies dan sindrom hemolitik uremik. ${ }^{10}$

Berdasarkan status nutrisi, sebagian besar pasien adalah gizi kurang dan gizi buruk. Asupan makanan yang kurang, muntah, diare, malabsorbsi makanan di usus halus dan demam akan mencetuskan defisiensi nutrisi yang serius dan menimbulkan supresi sistem imun, anak mudah terinfeksi sehingga tetap berada dalam lingkaran setan malnutrisi dan infeksi. ${ }^{20}$ Angka kesakitan diare akut akan meningkat 1,25 kali pada anak dengan gizi kurang (<-2SD) sedangkan pneumonia meningkat 1,86 apabila dibandingkan dengan anak gizi baik. ${ }^{21}$ Penelitian Winter $\mathrm{dkk},{ }^{22}$ sebagian besar pasien gizi buruk dijumpai atropi mukosa villi duodenum. Pada penelitian yang dilakukan di unit diare Rumah Sakit Muhimbili National tahun 2008, dari 50 pasien yang dirawat, 29 orang pasien meninggal dan sisanya sembuh dengan lama rawatan yang terbanyak yaitu $4-10$ hari. $^{18}$ 
Gejala klinis pasien bervariasi dengan predominan diare diikuti dengan gejala lainnya berupa demam dan muntah $(73,3 \%)$, batuk $(14,5 \%)$ dan kejang (6\%). Gejala yang dijumpai umumnya tergantung penyebabnya, berupa nyeri perut, demam, diare, mual dan/atau muntah, buang air besar berdarah. ${ }^{1}$ Pada penelitian yang dilakukan di Amerika ditemukan empat tanda prediksi terbaik derajat dehidrasi yakni waktu pengisian kapiler $>2$ detik, tidak ada air mata, keadaan umum, dan mukosa membran yang kering. ${ }^{23}$ Penggunaan waktu pengisian kapiler dapat memperkirakan jumlah kehilangan cairan yakni bila waktu pengisian kapiler 2-2,9 detik diperkirakan kehilangan cairan sebesar 50-90 mL/kgbb, waktu pengisian kapiler 3,0-3,5 detik : 90-110 mL/kgbb, waktu pengisian kapiler 3,5-3,9 detik : 110-120 mL/ kgbb dan waktu pengisian kapiler $>4$ detik: $150 \mathrm{~mL} /$ kgbb. ${ }^{24}$ Menurut Guandalini, ${ }^{15}$ terdapat tiga tanda prediksi derajat dehidrasi pada anak diare yakni waktu pengisian kapiler, pola pernafasan, dan turgor kulit yang abnormal.

Komplikasi yang diperoleh pada penelitian ini adalah gangguan keseimbangan elektrolit $(62,5 \%)$, sepsis $(20,5 \%)$, renjatan hipovolemik $(8,4 \%)$, bronkopneumonia $(2,4 \%)$, dan ensefalitis $(1,2 \%)$. Pada penelitian Mahmood dkk, ${ }^{25}$ didapatkan komplikasi diare akut pada anak malnutrisi yaitu gangguan keseimbangan elektrolit, asidosis, syok, dan septikemia. Shiiharaa $\mathrm{dkk},{ }^{26}$ melaporkan 2 kasus ensefalitis/ ensefalopati yang berhubungan dengan diare akut dan muntah yang disebabkan oleh rotavirus; kasus pertama disertai dengan gejala penurunan kesadaran dan kejang sedangkan kasus kedua dengan penurunan kesadaran dan gangguan deviasi mata.

Diperoleh kadar rata rata hemoglobin 11,3 (g/dL), hematokrit 33,8 $(\%)$, leukosit $15.360\left(/ \mathrm{mm}^{3}\right)$, natrium $135(\mathrm{mEg} / \mathrm{L})$, kalium 3,0 ( $\mathrm{mEg} / \mathrm{L})$, dan klorida 109 (mEg/L). Pada hasil laboratorium terlihat tidak dijumpai proses hemokonsentrasi, hal ini disebabkan karena pengambilan spesimen darah dilakukan setelah atau saat rehidrasi. Leukositosis mungkin disebabkan karena pasien didominasi dengan gizi kurang dan gizi buruk sehingga sistim imun yang menurun akan mempermudah terjadinya infeksi sekunder. Bila dehidrasi yang terjadi karena diare, terdapat mekanisme homeostasis yang akan mempertahankan cairan dan $\mathrm{NaCl}$ tubuh, sehingga konsentrasi natrium serum normal. Bila disertai muntah maka asupan cairan menurun sehingga kehilangan cairan lebih besar dibandingkan kehilangan natrium dan mengakibatkan hipernatremia. Hiponatremia terjadi bila diare hebat dan asupan cairan yang kurang, dijumpai juga gangguan kalium dan kalsium. ${ }^{24}$

Di antara 20 sediaan yang dilakukan pemeriksaan feses lengkap dan kultur feses diperoleh Kandida menempati posisi terbanyak (75\%). Kandida sp sering terkolonisasi pada mukosa saluran cerna. Terdapatnya Kandida dalam jumlah sedikit dalam tinja umumnya masih normal dan tidak patogenik. Kandida dapat diidentifikasi dengan konsentrasi yang tinggi pada tinja anak yang malnutrisi, sering berhubungan dengan diare dan telah dilaporkan sebagai patogen tunggal dalam tinja anak dengan diare. ${ }^{27}$ Kandida diduga juga sebagai penyebab diare yang berhubungan dengan penggunaan antibiotik pada bayi. ${ }^{27,28}$

Kekurangan penelitian ini adalah keterbatasan data yang diperoleh dari rekam medik dan pemeriksaan yang menunjang terhadap berat ringannya dehidrasi belum diterapkan sepenuhnya. Sebagai kesimpulan penelitian kami adalah kebanyakan pasien diare akut dehidrasi berat di ruang perawatan intensif RSUP. Prof. Dr. R.D. Kandou Manado dijumpai pada bayi lakilaki dan gizi kurang. Keluhan tambahan pasien adalah demam, muntah, batuk dan kejang. Hipokalemia, sepsis, renjatan, bronkopneumonia, dan ensefalitis merupakan komplikasi yang sering dijumpai. Kandida merupakan kuman patogen yang terbanyak dijumpai pada pemeriksaan feses.

\section{Daftar pustaka}

1. Johnstons B.C. Methodological issues in randomized trials of pediatric acute diarrhea: Evaluating probiotics and the need for standardized definitions and valid outcome measures (thesis). Alberta: 2009.h.1-212.

2. Nager AL, Wang VJ. Comparison of nasogastric and intravenous methods of rehydration in pediatric patients with acute dehydration. Pediatrics 2002;102:566-72.

3. Vafaee A, Moradi A, Khabazkhoob M. Case-control study of acute diarrhea in children. J Res Health Sci. 2008;8:25-32.

4. Web A, Starr M. Acute gastroenteritis in children. Australian Fam Physician 2005;34:227-31.

5. Guandalini S. Acute diarrhea. Dalam: Walker AW, Goulet O, Kleinman RE, Sherman PM, Shneider BL, Sanderson IR, penyunting. Pediatric gastrointestinal disease: pathophysiology, diagnosis, management. 
Toronto: BC Decker Inc; 2004.h.66-179.

6. Guarino A, Albano F, Ashkenazi S, Gendrel D, Hoekstra JH, Shamir R, dkk. Paediatric infectious diseases evidence-based guidelines for the management of acute gastroenteritis in children in Europe: executive summary. Pediatr Gastroenterol Nutr 2008;46:S81-122.

7. World Health Organization (2005) The treatment of diarrhea: A manual for physicians and other senior health workers. Diunduh dari: http://whqlibdoc.who.int/ publications/2005/9241593180.pdf Diakses pada tanggal 6 Mei 2009.

8. Parashar UD, Bresee JS, Glass RI. The global burden of diarrhoeal disease in children. Bull World Health Org 2003;81:236-44.

9. Kosek M, Bern C, Guerrant RL. The global burden of diarrhoeal disease, as estimated from studies published between 1992 and 2000. Bull World Health Org 2003;81:197-204.

10. Guandalini S., Frye R.E. Diarrhea. Diunduh dari: http:// www.emedicine.medscape.com Diakses pada tanggal 01 Agustus 2009.

11. O'Ryan M, Prado V, Pickering LK. A millennium update on pediatric diarrheal illness in the developing world. Semin Pediatr Infect Dis 2005;16:125-36.

12. Guandalini S, Dincer AP. Nutritional management in diarrhoeal disease. Baillieres Clin Gastroenterol. 1998; 12:697-717.

13. Vernacchio L, Vezina RM, Mitchell AA, Lesko SM, Plaut AG, Acheson DWK. Diarrhea in American infants and young children in the community setting: Incidence, clinical presentation and microbiology. Pediatr Infect Dis J. 2006;25:2-7.

14. Farthing M., Lindberg G., Dite P., Khalif I., Lindo E.S.,Ramakrishna B.S. Acute diarrhea. Dalam : World Gastroenterology Organization practice guideline. WGO, 2008.

15. Guandalini S. Acute diarrhea in children in Europe: Do we know how to treat it?. J Pediatr Gastroenterol Nutr 2008;46:77-80.

16. Management of the patient with cholera. Dalam: World Health Organization emerging and other communicable diseases, surveillance and control. Diunduh dari:
Diakses pada tanggal 01 Agustus 2009.

17. Baqui AH, Black RE, Sack RB. Epidemiological and clinical characteristics of acute and persistent diarrhea in rural Bangladeshi children. Acta Paediatr Suppl 1992;361:15-21.

18. John S, Nuru P. Admission patterns and outcomes of paediatric patients admitted at the diarrhea unit of Muhimbili National Hospital (MNH). Official Publication of the Tanzania Medical Students' Association ffi. Diunduh dari: http:// ajol.info/index.php/dmsj/article/viewFile/49591/35919. Diakses pada tanggal 01 Agustus 2009.

19. Mallory MD, Kadish H, Zebrack M, Nelson D. Use of a pediatric observation unit for treatment of children with dehydration caused by gastroenteritis. Pediatr Emergency Care $2006 ; 22: 1-6$

20. David S, Lobo ML. Childhood diarrhea and malnutrition in Pakistan, part I: Incidence and prevalence. Nurs J Pediatr 1995;10:1-6.

21. Anonymous. Child health research project research results and policy formulation on nutrition and micronutrients. Diunduh dari: http://www.harpnet.org/doc/chr_results.ppt. Diakses pada tanggal 04 Agustus 2009.

22. Winter TA, O'Keefe SJ, Callanan M, Marks T. Effect of severe undernutrition and subsequent refeeding on gut mucosal protein fractional synthesis in human subjects. Nutrition. 2007; 23:29-35

23. Brewster. Dehydration in acute gastroenteritis. J Paediatr Child Health 2002;38:219-22.

24. Finberg L. Dehydration in infancy and childhood. Pediatr Rev 2002;23: 277-81.

25. Mahmood R, Khalid Y, Iqbal SM, Masood T. Complications of acute diarrhea in malnourished children. Ann King Edward Med Coll 2006;12:307-9.

26. Shiiharaa T, Watanabea M, Honmaa A, Katob M, Moritac Y, Ichiyamad T, dkk. Rotavirus associated acute encephalitis/encephalopathy and concurrent cerebellitis: Report of two cases. Brain Develop 2007;29:670-73.

27. Vaisnavi C,Kaur S, Prakash S. Speciation of fecal candida isolated in antibiotic- associated diarrhea in non HIV Patient. Jpn J Infect Dis 2008;61:1-4.

28. Forbes D, Camer-Pesci P, Ward PB. Faecal candida and diarrhea. Archs Dis Child 2001;84:328-31 